\title{
FOUR FACTORS ARE IN FORCE PANDEMIC JOINTS TO INITIATE AN ILLICIT DUAL USE TECHNOLOGIES TRANSFER FROM UKRAINE
}

\author{
Iegor Kartuzov ${ }^{I}$ \\ ${ }^{1}$ Department of Political Science, European Studies Unit, University of Liege, Liege, Belgium \\ E-mail: iegor.kartuzov@student.uliege.be \\ ORCID: https://orcid.org/0000-0001-7493-674X
}

ARTICLE INFO

Article history:

Received date 18.05.2021

Accepted date 22.06.2021

Published date 30.06 .2021

Section:

Technology transfer

DOI

$10.21303 / 2313-8416.2021 .001919$

KEYWORDS

export control

covid pandemic

dual use technology

illicit technology transfer
ABSTRACT

An objective of this effort is a quick recap to assess the underpin barriers of transfer of technologies appeared in Ukraine after acquiring the Independence and those developed of today and to highlight and evaluate an impact of political, historical, mental and other factors affecting the science and as a consequence leakage of technologies abroad. Of importance is also a question if a current COVID-19 pandemic will join these factors if it initiates an illicit transfer of dual use (DU) technologies from Ukraine as it was in 1990s and how it affects an efficient and proper functioning and optimization of transfer of technologies process, and that is quite a challenge nowadays.

Investigated problem. The process of technology transfer and specifically that one of DU as a whole is neither simple nor systematic and far from being that perfect, especially when it deals with dual-use technologies and at present reduced to a short relationship between supplier/recipient only. The experience and practice show that it is a rather complicated, multi-leveled and multi-players process which is impacted and follows several factors and conditions that determine its success and/or failure at the end.

The main scientific results. The development of dual use technologies continues in a quagmire of conflicting interests and technology transfer export control rationales. There are historical, mental and political-military considerations where a state's decision to develop weapon systems or related applications can be assessed not only as a function of perceived levels of threat to its security, but also as a need to respond and/or step forward to potential technological innovations; and second, the fundamental conceptual differences in appreciation among countries of the right to possess different advanced weapons systems for defensive or offensive purposes.

The result of this endeavor makes a solid ground floor for further debates in terms of political science, export control regulations and factors affecting transfer of sensitive technologies.

(C) The Author(s) 2021. This is an open access article under the Creative Commons CC BY license

\section{Introduction}

The transfer of high-tech technologies for Ukraine over the years of its independence and nowadays is one of the key factors in stabilizing a development of strategic industries (defense-industrial complex, aviation, rocket-space engineering, etc.). A concept for implementation of state policy on import substitution and diversification of imports of supplies of goods for the needs of strategic industries, developed by the Cabinet of Ministers (Cabinet of Ministers of Ukraine, Resolution N471 of June 12, 2020) [1], outlines the ways to resolve traditional problems of transfer of dual-use technologies and strategic goods.

The need to resolve this issue at the external state level is caused by a specificity of evolution of political and mental factors affecting the transfer of technologies in transition period from the totalitarian regime of the former Soviet Union to an economically difficult format of the Union of Independent States (CIS). The factors influencing the transfer of technology, whether it is simply technology or dual-use technology, can be divided into four main groups:

1) political;

2) legal;

3) socio-cultural (mental);

4) technical. 
It should be emphasized that in real life they are so interrelated that sometimes it is impossible to clearly determine which group this or another factor belongs to, as well as assess its impact on technology transfer and take into account its value and twisting with others. From the point of view of an effectiveness of implementation of transfer of dual-use technologies in Ukraine, a deep significance and problematic nature of each group differ significantly. The final determinants of success are groups of political and mental factors, as they are more mobile in time, meanwhile, legal and technical factors are documented over a fairly long period of time. It is the fixed provisions adopted under certain political and mental factors that cause problems with changes in politics and mental behavior of society. These changes in Ukraine are rather kaleidoscopic. The technical and legal factors affecting technology transfer are developed by the international community and do not elicit much comment. They were officially adopted and reflected in the appropriate Ukrainian documents, however, their implementation in real life due to a transformation taken in political and mental driving forces led to a deep collapse of transfer of dual-use materials science technologies in Ukraine. Therefore, a transformation of political and mental factors during the transition of Ukraine from the position of a key republic of the Soviet Union into a sovereign "independent" European country has to be evaluated.

\section{1. The object of research}

To evaluate and clarify four factors :historical, political, technical and mental for an impact of transfer of dual use materials science technologies requires to rate and clarify some of ramifications which are often discussed in the context of non-proliferation debate of military technologies and national security. Of importance is also a question if the COVID-19 pandemic will join these factors and if it initiates an illicit DU technologies transfer from Ukraine as it was in 1990s and how it affects an efficient and proper functioning and optimization of transfer of technologies process, and that is quite a challenge nowadays.

\section{2. Problem description}

The intricate nature of dual-use technologies and their potential for enhancing Ukrainian and other economies make them fundamental to both R\&D and inexhaustible political debates. The blurring of civilian and defense industrial bases and the increase in issues with uncertain dual-use features make distinguishing between civilian and military products and platforms more difficult and complicate the issues of export control and technology transfer.

Mechanisms for actual viz. commercial transfer of production technologies of advanced materials of dual-use virtually does not exist and there are strong political, economic, security and legal reasons. Despite the above a transfer of sensitive technologies and conditions associated with it have continued to ignite a huge interest in the last decade worldwide. The process of technology transfer as a whole is neither simple nor systematic and far from being perfect as of yet, especially when it comes to DU technologies.

Thus, this endeavor makes an effort to analyze and scrutinize four factors and another one recently joined - the pandemic, staying between technology supplier/recipient and future prospects and real steps forward. The study employs qualitative methodology and is under the umbrella of a descriptive research design to agree on historical, technical, political, and mental implications for a transfer of sensitive technologies and state's security. Political, and legal analysis are conducted in relation to these technologies, actions and questions popped up nowadays associated. This descriptive research portrays a rather accurate profile of current situation happened around DU technologies in Ukraine. This design offers a profile of described relevant aspects of the problem of interest from author's individual perspective.

Social and cultural factors (mental, historical) form a lifestyle, work, thinking, consumption and significantly impact on all spheres of activity (scientific, political, etc., including technology transfer) in a particular country. All this is also aggravated and supplemented by the historical factor (country's evolution), which plays an important role in a sociality and mentality of a society. New trends in life, competition, etc. create a new type of thinking for scientists, businessmen, politicians, etc. According to the famous physicist M. Born, "science became a matter of national importance ... Science became an integral part and the most important part our civilization, and scientific activity directly affects the development of civilization". Various legislative and gov- 
ernmental factors influence a level of existing opportunities and threats of technology transfer. National and foreign governments may be its key regulators. This means that the most important aspect for technology transfer may be an assessment of state's political environment. The assessment is carried out by clarifying the political and legal factors affecting technology transfer. There are many factors, and even more combinations of those; thus, let's highlight and list the most common: the balance of political forces in state, relations between business and government, patent law, government regulation, political conditions in foreign countries, government relations with foreign states, changes in tax legislation, changes in customs service, etc. Undoubtedly, the success of innovation processes in Ukraine mainly exists die to the use of R\&D works developed to ensure the industrialization and development of defense industry of the former USSR. From the very first years of Ukraine's existence as an independent state - the initial period of transition to a global market economy took place, firstly, under the close attention of the world's community, and secondly, in the process of building a competent transition strategy for the CIS countries (where Ukraine occupied one of the leading positions in the development of advanced technologies), which was attended by professionals of the highest level, who sincerely believed in a prosperity of the country and wished it, thirdly, when freedom of speech and publication still reigned in a stream of broken democracy. In practice, an implementation of these postulates is a fairly reliable path to the economic and spiritual development of a new significant European country. Nevertheless it did not happen due to a protracted crisis of the Ukrainian economy and industry, corruption, shadow economy, difficulties of formation of new social system, etc.

The Committee for State Security (KGB) [2] never once during the years of the communist regime allowed an analysis of transformation of the highest echelon of power. The Communist Party has been overthrown, but a market economy requires an order and a strong state. This is evidenced by economic science, and the "new" cadres, who came to power, trumpet about it. Nevertheless, these cadres are not the second, but rather the third echelon of the same party functionaries who were not the best representatives of the school of government brought up by the system of the Soviet Communist Party.

This is the starting transformation for the factor 1 - "the highest echelon of power." Let's move on to the factor 2 - "material component". All governments of the analyzed period (and it should be noted that they changed each other very quickly) declared that Ukraine did not have funds to implement a revival program. For a number of reasons, large volumes of emerging private capital have so far been sluggishly invested in real production. A role is played by the fact that in a large number of cases this new private capital is far from an impeccable origin and is in no hurry to emerge from the shadows. It should be noted that, without exception, the countries of economic "miracle of revival" received a bunch of foreign investments. During this time, the inflation-destroyed industry suffered fantastic losses due to the severing of cooperative and financial ties with parts of the former Soviet Union, nevertheless, so far it physically exists and has not been physically destroyed (as was the case in Germany and Japan). Thus, the existing flagships of high-tech industries (rocket industry, aviation, metallurgy, energy and turbine construction) on a global scale are stifled by taxes, a shortage of working capital, a prehistoric system of barter settlements, an extremely disenchanted financial system, etc.

The Academy of Sciences of Ukraine had a high and internationally recognized authority even against the background of the powerful Academy of Sciences of the USSR, shaping the image of Ukraine as a powerful scientific and technical power in the world, especially in the field of materials science. genetics, programming and some other sciences. Its condition is deplorable and continues to fall catastrophically. In 2020, the volume of expenditures on the total funding of the state budget for the Academy amounted to 4.62 billion UAH [3]. It seems an astronomical sum. In practice, this amount provides only two-thirds of minimum needs of the Academy. The annual budget for 170 institutions of the National Academy of Science of Ukraine (NASU) makes the budget of a well-off American university. Needless to say, for example, that the Max Planck Scientific Society in Germany, which annual budget from the state a few years ago arrived at 8.5 billion euros, or about 255 billion UAH, yet the structure of German Academy of Science is similar to NASU. In general, the funding of science and education over the years decreased by at least five times, and if to take into account the loss of strong financial support for scientific work from industry (contractual works), the overall situation is completely deplorable. This is the initial 
conversion under the factor 2 (financial component). Initial conversion under the factor 3 - "Market". world experience shows that the entire complex pyramid of economic recovery, based on the production of high-quality competitive products, is justified only when an appropriate market is formed. The aforementioned factors (high technology, qualified personnel, strong and not corrupted government, etc.) are necessary conditions, and only the presence of the market (and a confident position in it) is a sufficient condition and is of great importance for future success. Market demand, sales, market stability determine the initial transformation of mental factor (sub factor 4 - "people"). After gaining the independence, Ukraine had the highest rank of scientific and engineering personnel, possessed the most authoritative science in the world, which in the "Wild, Wild West" was also considered as one of the most powerful in the world. Perhaps the most clear idea of this transformation was formulated in an interview of one of the leading economists of Ukraine, Oleg Belorus, who worked for many years in international organizations and reliably knew the opinion of the international community: "When I worked at the UN, as the director of the Department of Industry, Science and Technology, I was always proud of the fact that according to the UN classification, Ukraine was considered a highly developed state, one of the top ten countries in the world. Today it is a land of beggars. Absurd!" [4]. This is an emotional assessment; nevertheless, it is confirmed in a special report of the UN international commission that studied the situation in Russia. Conclusions of the commission, unfortunately, fully relate to Ukraine and convincingly show the continuing impoverishment of most of the country's population, which has caused, in particular, the emergence of the phenomenon of "new bags" - a stratum of highly educated people. The presence of qualified specialists working in spheres vital for human development (science, culture, education, health care, high technologies) does not mean an individual perspective of overcoming poverty. Over the last decade, the possibilities and potential of domestic science under the project of the 1990 model (before the collapse of the Soviet Union) suffered irreparable losses: thousands of first-class specialists left to work abroad, tens of thousands left into business, trade and joined the army of unemployed. In 2019, 2,270 young scientists worked in scientific institutions of the National Academy of Sciences of Ukraine, which is $15 \%$ less than in 2018. The number of young scientists - candidates of sciences decreased by $5 \%$. Compared to 2013 , these figures are $32 \%$ and $24 \%$, respectively [3].

The COVID-19 problem that emerged in 2020 has exacerbated the above problems. Widespread quarantine restrictions and daily reports from the "COVID front" temporarily muffle and distract from unpleasant economic news, but they have not gone anywhere: the fever on the stock exchanges continues, as does the turbulence of currency quotes and oil prices. All this is evidence of the already onset global crisis caused by the COVID-19 pandemic, which is unlike any other. Its further consequences are still unpredictable, and therefore, the prospects for economic recovery also remain uncertain. Nevertheless, it is already clear that the pandemic has dealt a serious blow to the economies of all countries all over the world, for example, the Spanish economy contracted by as much as $18.5 \%$ and showed the sharpest quarterly collapse among the EU countries, Portugal - by $14.1 \%$, France - by $13.1 \%$. At the same time, the GDP of a number of Baltic and Eastern European countries decreased not so much - for example, the GDP of Lithuania showed a decline of $5.1 \%$, Latvia $-7.5 \%$, the Czech Republic - $8.4 \%$ [5]. For France, the $13.1 \%$ drop in GDP recorded in the second quarter was a record since the Second World War. Germany, the largest market in the Eurozone, was thrown back by the crisis to the level of 2011 ( $-10.1 \%$ compared to the previous quarter). The Italian - to the level of 1990s (-12.4\%) [5].

In July, the heads of the EU countries agreed on a budget for 2021-2027 and approved a plan to recover the economy from damage caused by the coronavirus pandemic. The total budget amount is a little more than 1 trillion EUR, the cost of the plan is 750 billion EUR. The funds included in the recovery plan will be issued to European countries in the form of grants (390 billion euros) and loans (360 billion euros). The EU plans to borrow funds for a formation of an "anti-crisis fund" on international financial markets - the EU plans to repay these loans no earlier than 2058. Along with a reduction in GDP in the Eurozone at the end of this year, the number of corporate bankruptcies will significantly increase, analysts at Coface say [6]. For example, in Germany, the number of bankruptcies at the end of 2021 will grow by $12 \%$ compared to 2019 , and this figure is the lowest among European countries. In France, the number of bankruptcies is expected to increase by $21 \%$, in Spain - by $22 \%$. The most significant increase in the frequency of bankrupt- 
cies is expected in the Netherlands ( $+36 \%)$ and Italy $(+37 \%)$, and all this is only approximate and vague. The COVID-19 pandemic is projected to go from 71 million to 100 million people globally extremely poor, offsetting previous progress in poverty reduction and the first since 1998 increase in extreme poverty worldwide [7].

The United Nations conducted over 50 socio-economic studies. It follows from the conclusions of UN experts that since March 2021, 84 percent of Ukrainian families faced a drastic decrease in their income, 43 percent - with the loss of a job by at least one of family members. At the end of the first half of 2020, the poverty level in Ukraine was $51 \%$ - such an assessment was made by the Institute of Demography and Social Research named after Ptukha, NASU and was voiced by its director Ella Libanova in an interview with LIGA.net. "This is an estimate based on the latest data from the State Statistics Service on income and consumption, which we are monitoring. Now this figure is probably higher." According to her opinion, a poverty level indicator calculated by IDSI is based on the "estimated living wage" - and as of mid-2020 it made 3845 Ukrainian hryvnia (UAH). At the same time, the "official" minimum, which the Ministry of Social Policy operates below, is 2027 UAH [8] Recently, the State Statistics Service released the publication "Self-Assessment of Their Income Levels by Households in 2019". The data were obtained in the course of a sample survey of the living conditions of households. According to the State Statistics Service, $65.3 \%$ considered themselves poor. Another $33.6 \%$ did not consider themselves to be poor, but also not to the representatives of the middle class. $1.1 \%$ of citizens consider themselves to be the middle class. At the same time, the State Statistics Service [9] could not identify citizens who consider themselves rich. Today one may state that Ukraine is a country of massive and all-embracing poverty - a society of a "two-tiered" type, which may serve as a classic illustration of social polarization: $99 \%$ of poor and $1 \%$ of super-rich, a gap among those grows every day. In 2021, a level of minimum wage in Ukraine makes 6500 UAH that is only 198 EUR [13]. This key social standard is not commensurate with the European level of real income, which Ukrainian neoliberal officials are so fond of referring to. The minimum wage in Belgium is now 1626 EUR, in Germany 1610 EUR and in France 1555 EUR. However, the level of well-being of Ukrainians is incomparable even with the indicators of rather weak European economies. For example, in Greece, ruined by reforms, the minimum wage is 758EUR, in Poland - 614 EUR, in Estonia - 584 EUR, in Latvia - 500 EUR, in Hungary - 442 EUR, in Romania - 472 EUR, and in Bulgaria - 332 EUR [14].

Verkhovna Rada Vice-Speaker Olena Kondratyuk [10] believes that about 19 million people in Ukraine are below a poverty line. In 2020, the poverty rate in Ukraine rose to $50 \%$. According to her, research by international organizations showed that the poverty level in 2020 due to the pandemic in Ukraine increased to $50 \%$. In this regard, she believes that the parliament should challenge the government to develop a new strategy for overcoming poverty. "According to many international organizations, the poverty level in Ukraine has grown to $50 \%$, below the poverty line is about 19 million of Ukrainians. Therefore, the Verkhovna Rada must challenge the government to urgently approve a strategy and a set of measures to combat poverty in Ukraine until 2030 “ Kondratyuk said [11].

The aim of research is a quick recap to assess the underpin barriers of transfer of DU technologies appeared in Ukraine after acquiring the Independence and those developed of today.

\section{Materials and Methods}

Mechanisms for actual viz commercial transfer of production technologies of advanced materials of dual-use virtually do not exist due to a strong political, economic, security and legal reasons. Despite the above a transfer of sensitive technologies and conditions associated with it have continued to ignite a huge interest in the last decade worldwide. The process of technology transfer as a whole is neither simple nor systematic and far from being perfect as of yet, especially when it comes to DU technologies.

Thus, this endeavor makes an effort to analyze and scrutinize four factors plus another one recently joined - the COVID pandemic, staying between technology supplier/recipient and future prospects and real steps forward. The study employs qualitative methodology and is under the umbrella of a descriptive research design to agree on historical, technical, political, and mental implications for a transfer of sensitive technologies and state's security. Political, and legal analysis are conducted in relation to these technologies, actions and questions popped up nowadays asso- 
ciated. This descriptive research portrays a rather accurate profile of current situation happened around DU technologies in Ukraine. This design offers a profile of described relevant aspects of the problem of interest from author's individual perspective

\section{Results and discussions}

In Ukrainian society, in the process of implementing socio-economic reforms and transforming the existing system of power relations, the political elite periodically changes and rotates with each other, thus, the vector of the ruling elite towards science as a science. the whole also changes frequently. And as a result, since the day of independence, the vector of implementation of state policy in the field of science chosen by Ukraine has brought such a result that, in terms of financial support for $\mathrm{R} \& \mathrm{D}$, neither in absolute terms, nor in dynamics can be comparable with analogues in European countries. Ukraine is the only country that used the period of its development not to increase financial allocations for domestic science, but to decrease, the dynamics of which amounted to minus $9.3 \%$. As a result, the loss of qualified scientific personnel, a decrease in funding for scientific and scientific and technical work (SSTW). A total number of employees of research institutes and, most importantly, the number of specialists directly involved in SSTW constantly fall. According to the results of development of domestic science for 1991-2008 years a total number of scientists decreased 4.4 times in particular 626 Doctors of Sciences left Ukraine. During the period of 1996-2008, 1212 Ukrainian candidates of sciences have added to their migration biography the fact of a change in their country of residence. The number of specialists directly performing SSTW -4.6 times. The highest rates of decline were for 1995 (by $34.8 \%$ of total number of scientists and by $39.1 \%$ of specialists involved in R\&D in relation to 1991) [12].

There is also a leveling of science priority among other types of activity and a steady decline in the level of science-intensive GDP. This index quantitatively reflects the national scale of investments in $R \& D$, a significant component of which in Ukraine is the state budget. The situation with the level of knowledge-intensive GDP can best be described by a term "steep peak" rather than "recession", as at the end of 2018 this indicator (which amounted to $0.62 \%$ of GDP turned out to be half as much as in the mid of 1990s, that is, during the period that in the history of independent Ukraine was marked as a deep crisis of national economy (with a science-intensive level of $1.4 \%$ of GDP). Thus, the level of science-intensive GDP of critical 1990s is still quite a challenge for the Ukraine of today.

For the EU, this indicator in 2015 amounted to $1.96 \%$ of GDP, which is 3.3 times more than in Ukraine, in Singapore $-2.2 \%$ (or 3.7 times), in France $-2.27 \%$ (or 3.7 times), Germany $2.9 \%$ (or 4.8 times), USA - $2.72 \%$ (or 4.7 times), Finland $-2.87 \%$ (or 4.8 times), Japan $-3.28 \%$ (or 5.5 times), Republic of Korea $-4.2 \%$ (or 7 times) [13]. In addition, if to compare with former partners in CIS, in terms of high-tech level of GDP, Ukraine is significantly inferior even to some of them, for example, the Russian Federation (1.1\%, or 1.8 times, respectively).

Thus, Ukraine today suffers from a whole range of progressive socio-economic problems: impoverishment of population, unemployment, labor migration, and many other crisis symptoms. In this regard, it is important to mention the destruction of science as an important component of society and the state as a whole, and, consequently, national security. Some ruins remain from a society where education and science are constantly neglected, let alone the state and its place on the world stage. The innate talent and abilities of a person, not developed by education, perish. The outflow of talented young people who do not want to live in the outskirts of civilization suffers avalanche growth [14-16]. This mode of work is critically unfavorable for young scientists who en masse move to other fields of activity or emigrate from Ukraine to Europe, America and other developed countries. In 2019, 2,270 young scientists worked in scientific institutions of the National Academy of Sciences of Ukraine, which is $15 \%$ less than in 2018. The number of young scientists - candidates of sciences decreased by $5 \%$ if compared to 2013 , these figures are $32 \%$ and $24 \%$, respectively [3]. Of course, the results of such an attitude of the state to the problems of science were not long in coming. Due to insufficient funding, Ukrainian science is constantly losing its human and material and technical potential. For example, as of January 1, 2016, the number of researchers per capita in Ukraine became the lowest in Europe. Its indicator today is not only significantly lower than in scientifically developed countries (Japan, France, Germany), but also 
one and a half times lower than the indicators of Poland and Romania, which until recently were much inferior to Ukraine in scientific potential. Commenting on the current situation in Ukrainian science, Anatoly Shirokov, head of the NASU Workers' Union, noted: "In terms of a number of scientists per capita, Ukraine is slipping to the level of Albania - where, frankly, there is no developed science at all. The new version of the law on scientific and S\&T activities adopted this year is not being implemented - on the contrary, new problems popped up: funding is allocated for science less and less, and there has never been such a difficult situation as of today. Ukraine may lose science in the very near future: there would simply be no one to do a scientific research.'[17]. The opinion of the current president of the Academy of Sciences of Ukraine, Academician of the National Academy of Sciences of Ukraine Anatoly Zagorodniy, coincides Shirokov: "Being a scientist in Ukraine is a legitimized way of begging, said my friend, who is a candidate of science and a chemist by profession. After seven years at the research institute, he went to work for pharmacists with a salary of two thousand dollars. Do you agree with the thesis of legitimized begging?" [3] As for the salary in Academy of Science then, its basic level depends on a position, scientific degree and title, experience and allowances provided by the law. Accounting for all this a junior researcher on full employment receives from 213 to 274 euro, a researcher - from 228 to 304 EUR, a senior researcher - 274 to 456 EUR, a leading researcher - 304 to 548 EUR, chief researcher, head of department - 304 to 608 EUR. The salaries of academics and corresponding members, as well as all other researchers, are determined by a position and allowances. In addition to the salary, they receive lifelong salaries for academic titles: an academician about 5 thousand UAH per month, a corresponding member - 103 EUR. The size of these tuition fees has not been reviewed by the government since 2007.

The COVID pandemic has made a huge contribution to all of the above said factors. "The efforts that we make urgently now are designed to soften a blow of the pandemic and set Ukraine up for a post-crisis revival," said UNDP representative Dafina Gercheva: "We hope that after the pandemic, the country will be stronger and more stable than ever before." [18]. Meanwhile hundreds of scientists still leave the country looking for a better life and taking their knowledge and technologies.

The result of this effort makes a floor for further debates in terms of political science, export control regulations and factors affecting transfer of sensitive technologies worldwide.

\section{Conclusions}

The above-discussed groups and subgroups of four factors affecting the transfer of dual-use technologies are closely interrelated and possess a profound significance. Each step towards practice and optimization of transfer of materials science technologies in Ukraine should be carried out accounting for all groups, as well as specifics of high level of science intensity of advanced technologies for which, a stable market demand always exists. Unfortunately, Ukraine does not used the period of its formation as a sovereign European country yet not to increase budgetary financial allocations for national science, but to reduce those. This historical factor leads to a catastrophic change in mental factor. As a result, there is a steady fall of science importance among other activities in society, a decrease in science-intensive GDP and a super-catastrophic brain drain among young scientists both abroad and into other activities. The COVID pandemic has made a huge contribution to all of the above said factors when raised the poverty and uncertainty in the global community. Every COVID-19 affected nation [19] has felt a huge gap between rich and poor. Therefore, the search for ways to effectively overcome the problems associated with the newly appeared factor "pandemic" should be based primarily on a deep analysis of all socio-political, economic and historical processes that manifest themselves against the pandemic and to account for an interdependence and synergistic effects of those, thou.

\section{Acknowledgements}

This effort and the research behind would not have been possible without the exceptional support and initial impetus of my supervisor, prof. Dr. Quentin Michel. His enthusiasm, knowledge and exacting attention to every detail have been an inspiration and kept my work on track from my first encounter with political science and legislation referred particularly to transfer of dual use technologies in the EU and Ukraine. 


\section{References}

[1] Pro zatverdzhennia Prohramy diialnosti Kabinetu Ministriv Ukrainy (2020). Postanova Kabinetu Ministriv Ukrainy No. 471. 12.06.2020. Available at: https://www.kmu.gov.ua/npas/pro-zatverdzhennya-programi-diyalnosti-kabinetu-ministriv-t120620

[2] Knight, A. (1990). The KGB: Police and Politics in the Soviet Union. Unwin Hyman, 357.

[3] Krigel, M. (2020). Prezident NANU Anatoliy Zagorodniy: Esli ne prekratit ottok mozgov, nauka v Ukraine umret esche do serediny XXI veka. Available at: https://www.pravda.com.ua/rus/articles/2020/12/16/7276754/

[4] Skorokhod, V. V., Firstov, S. A., Kartuzov, V. V. (2005). Viktor Ivanovich Trefilov Life and work Memoirs Selected works. Kyiv: Publishing house Academperiodika.

[5] Europe and Central Asia Economic Update (2020). Fall 2020: COVID-19 and Human Capital. doi: http://doi.org/10.1596/ 978-1-4648-1643-7

[6] Coface. Available at: https://www.coface.ru

[7] Lakner, C., Mahler, D. G., Negre, M., Prydz, E. B. (2020). How Much Does Reducing Inequality Matter for Global Poverty? Global Poverty Monitoring Technical Note 13. World Bank Group Global.

[8] Kazhdiy vtoroy ukrainets nakhoditsya za chertoy bednosti, mnogie poteryali dokhody iz-za karantina (2021). Available at: https://censor.net/ru/n3244326

[9] Derzhavna sluzhba statystyky Ukrainy. Available at: http://www.ukrstat.gov.ua/

[10] Kondratiuk, O. (2021). The fight against COVID-19, tariffs, land, overcoming poverty and unemployment - that's what really worries citizens today and requires a reaction from the Parliament and the Government. Available at: https://www.rada.gov.ua/ en/print/207179.html

[11] Za chertoy bednosti okazalis okolo $19 \mathrm{mln}$ zhiteley Ukrainy. Available at: https://censor.net/ru/n3245284

[12] Maidanik, I. P. (2010). Intellectual migration in Ukraine in the context of international scientific cooperation. DEMOSCOPE, 405-406.

[13] Main Science and Technology Indicators. Available at: https://stats.oecd.org/Index.aspx?DataSetCode=MSTI_PUB

[14] Tarapov, I. E. (1994). Intellectual labor, science and education. Crisis in Ukraine. Kharkiv: Folio, 176.

[15] Minimalnaya zarplata v Ukraine 2021. Available at: https://buhgalter911.com/spravochniki/oplata-truda/razmer-minimalnoy-zarplaty/2021-g-950647.html

[16] Statutory minimum wages (2021). Available at: https://www.eurofound.europa.eu/data/statutory-minimum-wages

[17] Serdiukov, I. (2017). Nauka bolshe ne nuzhna: ukrainskie uchenye uezzhayut iz strany. Available at: https://ukraina.ru/ exclusive/20170113/1018148913.html

[18] Eksperty OON: pandemiya podtalkivaet Ukrainu k tyazheleyshey retsessii, no naikhudshego stsenariya mozhno izbezhat. Available at: https://news.un.org/ru/story/2020/09/1386142

[19] COVID-19 and human capital. Economic Report for the Europe and Central Asia Region. Office of the Chief Economist. World Bank Group, Fall 2020. Available at: https://openknowledge.worldbank.org/handle/10986/34518 